\title{
EDITORIAL: IN PASSING
}

On my desk is a copy of issue no. 144 of the French periodical $\mathrm{La}$ Revue Musicale, published in March 1934. I picked it up for $€ 4$ in a second-hand bookshop in Brussels and, frayed and auburn-tinted though it may be, it is one of the loveliest music journals I possess. It came with each group of four pages still as one sealed unit, the sides needing to be slit open with a sharp knife; mine were therefore the first eyes in 80 years to scan the contents of those particular inner pages. The cover has dark green lettering on a cream background, and articles are prefaced by handsome drawings and reproductions of woodcuts. La Revue Musicale appeared ten times a year and an annual subscription was 75 Francs; no differentiation was made between individual and institutional prices, but if one's finances were sufficiently buoyant, one could buy an 'Édition de luxe' for 150 Francs. The editor, Henry Prunières, kept office hours at 132-136 Boulevard Montparnasse on Fridays from $2.30 \mathrm{pm}$ to $4.30 \mathrm{pm}$. Alternatively, one could visit his staff on Tuesdays between $5 \mathrm{pm}$ and $6.30 \mathrm{pm}$ in the months November through July, to deliver one's copy or simply to gossip.

Partly what fascinates us about La Revue Musicale today are details like these, the differences from what we now consider to be the norm in journal publishing. Also fascinating is the eclecticism of its content: an elaborate lead article by poet and playwright Paul Claudel on 'Mystical Instruments' rubs shoulders with articles on Russian liturgical chant, on Beethoven's A minor Quartet Op. 132, on a new opera by Gian Francesco Malipiero, and with a cache of previously unpublished letters of the nineteenth-century pianist and composer Stephen Heller. We also enjoy the bluntness of Prunières himself as critic: his review of a new 446-page Italian tome entitled The Problem of Opera begins 'Un gros livre pour ne pas dire grand chose'. Most fascinating to me is not the content of which Prunières would likely have been most proud, the articles (though they remain of considerable interest to scholars today), but much of the subsidiary material: the laudatory reviews of works and composers almost forgotten (Marcelle de Manziarly) or cut down in their prime (Pierre-Octave Ferroud); the half-page ad for 'speedy, luxurious and comfortable' travel by boat and train between Paris Nord and London next to a small notice for Rachmaninov's recital in the Salle Pleyel on March 23rd; the adverts for holidays in the mountains by autocar (one following the route Napoleon took through the Alps following his return from exile on Elba) side by side with the announcement of new publications by Poulenc and Turina from the long-since defunct Rouart-Lerolle \& Cie.

Such publications are a delight not least because of their longevity. Prunières founded La Revue Musicale in 1920; publication was halted because of the circumstances of the war in 1940. Twenty years, some two hundred instalments. But even his achievement pales in comparison with that of Malcolm (professional name: Calum) MacDonald, who joined TEMPO as assistant to its then-editor David 
Drew in 1972, at the age of 24, becoming Managing Editor and finally Editor a few years later. His involvement with the journal therefore spans over 40 years. In 1972 TEMPO published its one-hundredth issue; the present issue is no. 270. More than 160 issues, therefore, have Malcolm's imprint on them. He also found time to write books (major studies of Schoenberg, Brahms, Havergal Brian, John Foulds, Varèse and others, as well as a guidebook to the city of Edinburgh) and articles and liner notes for innumerable CDs.

We met only once, at a lunch at the British Library organised by Cambridge University Press to discuss the handing over of the Editorship of TEMPO. It was a sunny day in April 2013. Malcolm had told me of his illness but he was then, to external appearances at least, in good shape. We talked health issues; he spoke about his dietary attitudes, his Chinese herbs. He was proud that he could still do heavy work in his garden. Regarding TEMPO, I had things to learn from him, but there was not so much to discuss; we saw eye to eye on pretty much every issue. Well, every issue but one: for Malcolm, modern music meant Schoenberg's generation and the line he traced from there to the present day. To me, 'modern music' is historical; my main professional interest was, and is, in new music, which for me begins after World War II. I told him that in order to focus more closely on the present I planned to knock half a century off TEMPO's remit. He gave me a twinkly smile.

At the end of 2013 TEMPO passed over from him to me and Reviews Editor Juliet Fraser. And now, late May 2014, he himself has passed away, all too soon. When we speak of 'struggling with an illness' we only partly mean that we want to kick the thing away for as long as we can; we also mean, and Malcolm certainly meant, that we will struggle to carry on with the worthwhile things of life until our bodies finally make it impossible. As we walked down Euston Road he told me of a book he hoped to write (about a sea captain, if I heard him right); and on 4 April, only a few weeks before he died, he emailed me to say:

\footnotetext{
I always thought I would use my non-Tempo time to write some music of my own, and I have plenty of small half-finished or rather half-begun projects I thought I would start by tidying up. Instead, out of nowhere has come this big orchestral piece for a huge bass- and percussion-heavy orchestra that no one could ever possibly want to programme (but I find that liberating): don't know how to describe it but it's a dark, grumbly piece a bit like a combination of Varèse (yes, there are sirens) with Allan Pettersson at his blackest, with a sort of clattery Ivesian march in the middle - not that I've got anywhere near the middle yet. I envisage it ending up about half an hour in length.
}

The piece was not finished, but the will to tackle so huge and ambitious a task in such circumstances is deeply moving.

Malcolm's legacy does not lie only in this journal, but he was associated with TEMPO for so long that acknowledging a successor might, for a lesser man, have been a difficult task. But he welcomed me into the role with the same generosity of spirit with which he'd welcomed the articles I submitted to him in years gone by, even though the music I wrote about must have seemed somewhat remote from his orbit. We can best pay our respects to his memory by carrying on the work that he himself carried on with such devotion and steadiness for so long. I'm sure that, in time, even some of the subsidiary material in TEMPO of the eighties, nineties, noughties - the ads, the news items, the font styles, even the paper size and quality (indeed, the very fact that it was printed on paper) - will come to seem as charming and quaint as the idea of Prunières advertising holidays by autocar 
or holding office hours on Friday afternoons. I think Malcolm, with his unpretentious wit and delight in the oddities of life, would have liked that.

If, like me, you overdosed on Morton Feldman when all those wonderful CDs began to appear in the early 1990s and in consequence don't listen to him all that much these days, the lead article in TEMPO 270, by Kevin Volans, may provide a way back in. Volans gives a fellow composer's perspective on Feldman's ideas and aspects of his compositional practice, striking a balance between personal response and objective commentary. Following this is the first extended study of the use of 'invented language' in the music of Volans's friend Claude Vivier, in an article by the young American composer and scholar Bryan Christian. The prevalence of these nonsense texts in many of Vivier's vocal works, attractive and enigmatic though they are, has sometimes proved a problem for singers who must somehow interpret and shape their long strings of meaningless vocables. Christian provides some historical reference points that allow us to see Vivier's practice in a fresh light.

TEMPO 270 also contains articles on two classics of the post-war avant-garde. Ligeti's Requiem is one of those early 1960s compositions that has always remained, despite its fame, a somewhat enigmatic piece. The American musicologist Jennifer Iverson explores the lesserdiscussed serial basis of parts of the work, and the particular alliance Ligeti configures between Webern and Bartók in this period of his musical thought. The Berlin-based scholar Makoto Mikawa offers a study of the little-known tape work Antithese by Maurico Kagel, describing the politically charged path Kagel treads between the dominant aesthetics of French musique concrète and German elektronische Musik. Finally, two somewhat younger artists in conversation: the Belfast-based English composer Piers Hellawell, whose beautiful black and white photographs of Harris, in the Outer Hebrides, adorn this issue; and the energetic and inspiring young conductor Ilan Volkov, the shaping force of the adventurous Tectonics festivals of new music that play in Reykjavik, Glasgow, Tel Aviv and (as of this year) New York.

In closing, we remember our distinguished colleague Reinhard Oehlschlägel (1936-2014), one of the founders and editors of the German periodical MusikTexte; and TEMPO 270 has a chorus of voices remembering Malcolm MacDonald, to whose memory this issue is dedicated. 


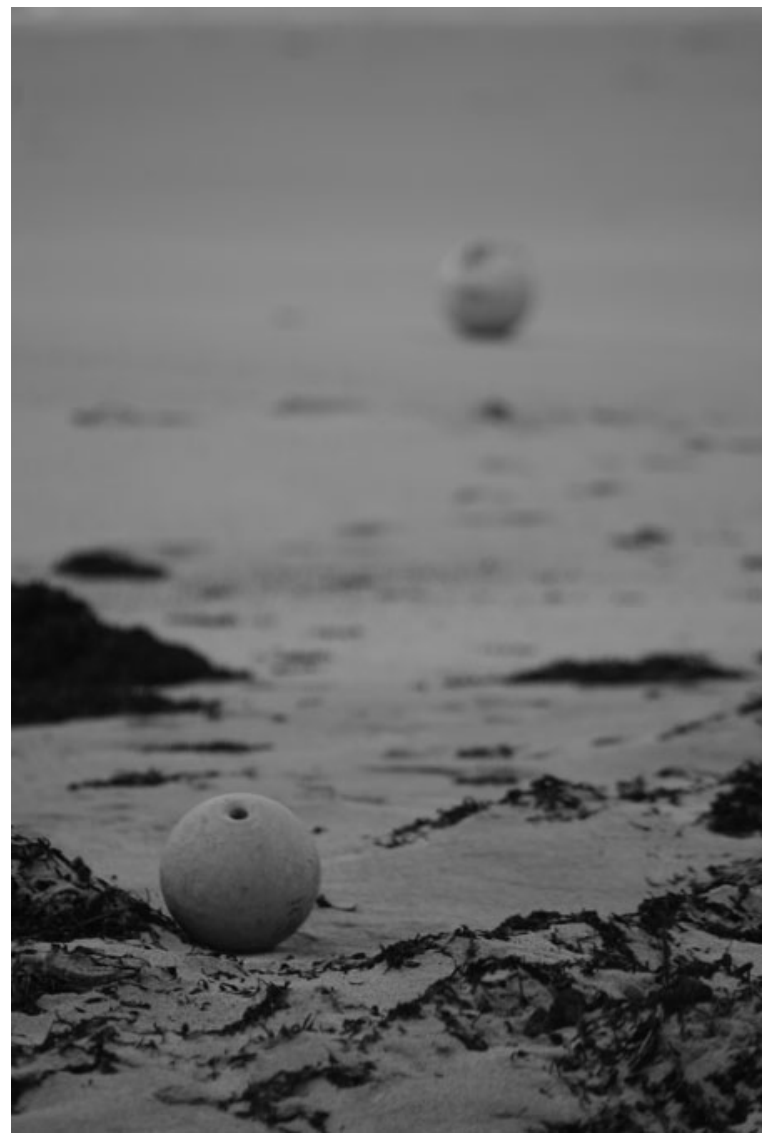

(C) 2010 Piers Hellawell, two floats, black and white print 